Јасмина М. АХМЕТАГИЋ ${ }^{*}$ Институт за српску културу Приштина - Лепосавић
Оригинални научни рад

Примљен: 09. 10. 2019.

Прихваћен: 12. 02. 2020.

\title{
ЕНЦИКЛОПЕДИЈСКА ФОРМА И ПАРАНОИДНА ЕПИСТЕМОЛОГИЈА У РОМАНУ СВЕТИСЛАВА БАСАРЕ
}

\begin{abstract}
На примеру романа Успон и пад Паркинсонове болести (2006), сагледаћемо начин на који Светислав Басара користи енциклопедијску парадигму, служећи се једним од њених централних топоса - архивом. Идејом архива као „колективног заборава света” писац мотивише апокрифну природу текстова од којих је сачињен роман - зборник архивских докумената које је у фасциклу објединио историчар Вознесенски. Басарину трансформацију енциклопедијске парадигме сагледавамо у контексту Борхесове идеје Вавилонске библиотеке (као пародирање) и Кишове Енциклопедије мртвих (као контрапункт). Призвано интертекстуално знање Басара испуњава конструктивистичком идејом: и архивско знање је креирано. Енциклопедијска форма у онтолошки несигурном свету поткрепљује параноидну епистемологију. Прича о прогнаној духовности препуштена је Паркинсону, а овај је реализује као наративни пројекат, рационалистички чврст и непропустљив за случајности. У нашем фокусу је суптилна Басарина игра са својим јунаком: иронијски га осветљавајући, али се криптично са њим поистовећујући, писац доследно опстојава у двозначном одговору на питање односа између постмодерне многострукости и параноидне ригидности.

Кључне речи: Светислав Басара, Успон и пад Паркинсонове болести, параноја, енциклопедијска форма, архив, текстуални универзум.
\end{abstract}

Најуспелији романи Светислава Басаре (Фама о бициклистима, Успон u пад Паркинсонове болести и Дневник Марте Коен) изграђени су на истом композиционом принципу: реч је о зборницима радова, чији потписници износе различите, често противречне тврдње о истој теми, било да ова има средишњи или периферни положај у тексту. Мада се Басари с разлогом пребацује маниризам, видљив у грађењу заплета, расплету, мистификовању, понављању једном нађених решења, чињеница је да је он у моделу романа зборника нашао адекватан облик за посредовање слике света без онтолошког утемељења, у којој важан простор припада заверама и конспирацијама, те параноидној свести савременог човека. Као што Фама о бициклистима тече

\footnotetext{
*jaca.a@eunet.rs
} 
кроз простор и време, на Исток и Запад, од средњег века до наших дана, Биографија Марте Коен у вези је са укупном геополитичком сликом коју мења однос према духовности, тако се и у Успону и паду Паркинсонове болести (2006) разматра појава светских размера. Истраживање биографије Демјана Лаврентијевича Паркинсона, „изумитеља страшне болести”, читаоца води кроз Русију, Отоманску империју и наше просторе, па и САД, будући да је забрана уласка Паркинсона на ту територију имала по њу кобне последице.

У обликовању текстуалног универзума у коме је све на парадоксалан начин повезано (баш зато што више ништа ни са чим није повезано) кључну улогу има Басарина стратегија објашњавања једног непоузданог феномена низом других, такође непоузданих, посредством псеудодокумената. Као ни за бициклисте, или Марту Коен, ни за Паркинсона се ништа поуздано не може рећи: под условом да је уопште постојао, Д. Л. Паркинсон је умро 1947. године у логору на Колими под лажним именом Кузњецов. Међутим, он можда и није постојао, можда је тек фиктивна личност Достојевског - централна тема је највишег нивоа непоузданости. У Успону и паду Паркинсонове болести пре свега се прати фама о једном феномену, с тим што су централни извори архиви Охране, НКВД-а, КГБ-а, Лубјанке. Роман у коме је важна тврдња да су „фундаменти модерних наука лажни” (Басара 2007: 175), подражава модел научног истраживања - архивски рад. Под контролом Државне безбедности, хиперболисаних димензија, а делокализовани, архиви постоје као некакав паралелни текстуални универзум. Писац предговора Касаткин даноноћно прати Вознесенског „по задатку Службе” (Басара 2007: 15), али се оглушује о њена правила и износи у јавност што је требало да спречи, садржај фасцикле Вознесенског са изабраним документима о Паркинсону. Због инфлације докумената - јер су архиви „колективни заборав света”, незванична историја човечанства, у њима су истине и лажи обједињене на начин који једва да допушта њихово разлучивање - више се ништа не може научно утемељити. Испоставља се да је научни метод тек субјективни одабир података, чиме је мотивисан и дисконтинуитет романескне нарације.

Борхесова идеја универзума као огромне библиотеке која садржи све могуће књиге, и преводе свих књига на све језике, у Басарином роману добила је пародијски облик: полицијски архиви су енциклопедијске књиге над књигама. Борхесов Библиотекар коме је доступан каталог са пописом свих књига Вавилонске библиотеке, због чега има статус Бога, у Басариној интерпретацији има лик Вознесенског, историчара са приступом свим архивима, који не може доспети ни до каквог поузданог знања, нити га може објавити. Борхесов енциклопедијски текстуални универзум творе узајамне кореспонденције сваког елемента са свим осталим - у Басарином се открива вишеструко фалсификовање, па су и све могуће повезнице фалш, те је сумња неизбежан одговор субјекта на такав оквир. Успон и пад Паркинсонове болести јесте хрестоматија текстова о Паркинсону и фрагмената његових списа „из којих пажљив читалац може реконструисати или бар наслутити обрисе његове доктрине" (Басара 2007: 27). Као што Вознесенски на основу делова треба да реконструише целину, и пред читаоцем стоји исти задатак: будући да су 
пред њим изводи из архива, у рецепцији дела он мора оперисати сумњом, а његов интерпретативни напор, у духу онтолошке, постмодерне поетике која „фрустрира интерпретацију” (Макхејл 1992: 150), неће бити награђен коначним сазнањем о предмету за који је заинтересован.

Пред обиљем докумената чије истраживање вишеструко надмашује дужину људског живота Вознесенски је принуђен да се ослања на интуицију, али се документима ипак мора обратити, јер то налаже принцип научности на коме почива доба у коме живи и, с тим у складу, расположивост архива. На крају, он добија само једну могућу верзију о предмету свог истраживања, што би добио и да је његова реконструкција Паркинсонове биографије почивала на другачијем приступу. Мотивација да одговори на питање „ко је, до ђавола, био тај Паркинсон и од какве је то болести боловао” (Басара 2007: 17), чини од његовог архивског истраживања детективски посао. Но, његов откривалачки импулс не може бити задовољен, те је Вознесенски тек пародија „когнитивног јунака детективске приче” (Макхејл: 147), а роман има псеудодетективску форму.

„Случајност” композиције даје сваком од текстова у Усnону и паду Паркинсонове болести смисао и функцију енциклопедијске одреднице и дозвољава нелинеарност читања романа. Басарин хотимичан труд да за све што се у роману тврди буде упућено на извор информисања, праћен је у исти мах подривањем њихове аутентичности, те функционише као стратегија пародирања документарности. У Успону и паду Паркинсонове болести, који је тек одломак архива (а овај је метонимија за свет), постоје веродостојни и веродостојнији извори, апокрифи, забрањени и заплењени текстови, цензурисане али не нужно и истините књиге и текстови, као и књиге-двојници, књиге-фалсификати, тако да се сучељавањем сведока, сведочења и извора ствара наративна напетост која не може бити разрешена. Именовање извора постаје празан знак, који открива константано процесуирање псеудодокументарности, а не потврђивање истинитости. Пролиферација докумената је метод одржавања несигурности, хотимичног неговања несазнатљивости у условима манипулисања информацијама - с највише инстанце одлучује се само о утилитарности знања, а не о његовој истинитости, и то је врста тоталитарног искуства које Басара оцртава у свом роману.

Према таквој, типично постмодерној слици света Басара заузима изразито критички став, који откривамо тек преиспитивањем његовог односа према централном јунаку, чија интерпретација открива низ узрока за слику света са којом се читалац суочава у роману. Између архивског, до крајњих граница непоузданог универзума и Паркинсонове ,доктрине”, сугерише се једнаком пажњом посвећеном њеном откривању и њеном садржају, постоји каузална веза, али док Паркинсон верује да објашњава узроке, читалац има разлога да мисли да је његова „доктрина” тек последица таквог света.

Заплет Басариног романа служи илустрацији централне тезе о „фалсификовању свега, свачега и свакога" (Басара 2007: 175), и у том је смислу Успон и пад Паркинсонове болести роман с тезом, коју поткопава ауторова лудистичка игра. Циљ је енциклопедијске форме да представи сву сложеност 
и противречност живота, међусобну испреплетеност и међузависност свих његових феномена, а површина архива - поједини одељци се подударају са величином Бугарске или бившег Совјетског Савеза - призива идеал Кишове Енциклопедије мртвих. Призвано интертекстуално знање писац, међутим, испуњава конструктивистичком идејом: његова „енциклопедија мртвих” садржи попис свега што се у животу збило, о чему се у јавности не сме сазнати ни реч, али и онога што се није збило - и архивско знање је креирано. Фокусиран на Паркинсона и „свету болест” кроз време и простор, Басара у свом роману обухвата просторни и временски тоталитет, различите гласове и перспективе, а енциклопедијска форма коју остварује ширином захвата и децентрираношћу - како се испоставља - као једино поуздано доноси свест о потпуној произвољности апсолутно сваке истине која је саопштена, те о бескрајним интерпретативним могућностима у којима су на снази различите комбинације података. Ако се Фама о биииклистима може сматрати у извесном смислу ,анти-књигом Кишовој Гробници за Бориса Давидовича” (Владушић 2007: 22), „Успон и пад је својеврсна анти-књига Фами о бициклистима" (Татаренко 2008: 27), али и анти-књига Енциклопедије мртвих, будући да се у басаријанском енциклопедијском свезнању губи разликовање лажи од истине, живих и мртвих. У таквом универзуму параноидно стање свести је консеквентно, а Паркинсонизам, ако судимо по ономе што производи, а не само по ономе како сам себе дефинише, у значајној мери у себе укључује и параноју, коју рађа жеља за тоталитетом знања у условима немогућности да се оно васпостави.

Реалност је условљена текстуалношћу, а не обрнуто: руску реалност су упропастили писци реалистичке прозе, како се у роману тврди, као што је Комунистички манифест постао државно уређење, а однос реалности и текста илуструје епизода са писањем Злочина и казне: новински текст доноси измишљену причу о злочину на основу које Достојевски уобличава роман, а овај утиче на студента Раскољникова да га спроведе у дело. Кад то имамо у виду, централно питање у роману није у ком смеру иде подражавање (од текста ка стварности или обрнуто), већ његова природа - мимеза претпоставља онтолошку стабилност, односно уверење да је онтолошка стабилност подражаваног неупитна. Подражавање које иде од текста ка стварности, а заправо од текста ка тексту, открива конструктивистичку природу света и доминацију текстуалности над стварношћу.

Проучавајући Паркинсонову биографију, Вознесенски је више сазнао о устројству и смислу архива него о предмету свог интересовања; исто се искуство уобличава и у процесу рецепције романа, на чију композицију утиче чињеница да предмет који је у фокусу не само да не може бити сазнат на потпун и веродостојан начин, јер би то било у супротности са архивском/ конструктивистичком природом света чији је део, него у некаквом изворном смислу уопште не може бити спознат. Циљ је Паркинсонизма, обележеног месијанским осећањем и гордошћу, инфицирање других, а Басара се, ангажујући вантекстуално читаочево знање (криптично се повезује са својим јунаком приписујући му свој есеј о хелиоцентризму), легитимише као следбе- 
ник Паркинсонових идеја. Иронија којом је повремено осветљен Паркинсон понавља ону којом јунак као аутор текста о Бемеу окружује великог мистика и потиче од Басарине аутоироније спрам властите месијанистичке идеје и гордости. Тако се у односу Паркинсона према свом јунаку - Јакобу Бемеу - огледа однос Светислава Басаре према Демјану Лаврентијевичу Паркинсону. Ауторов тематски интерес садржан је у чињеници да се „света болест” шири читањем о њој, што потврђују и разбољевање Вознесенског у току истраживачког рада.

Енциклопедијска форма у онтолошки несигурном свету поткрепљује параноидну епистемологију: будући да сазнајни процеси не воде истинском знању, тј. задовољењу мотива с којима су покренути, они се преображавају у настојање да се овладавањем најширим могућим кругом информација о предмету истраживач разабере у фалсификовању. Уместо чињеница о свету сазнајни субјекат упознаје силе које учествују у креирању истина о свету, тј. субјекат сагледава мрежу у коју је уловљен. Тајне службе, прогони, цензуре и фалсификовања толиких су размера (а у исти мах апсолутна тајност не постоји) да је читалац ухваћен у мрежу информација и полуинформација, у којој треба да освести њихов потпуни привид. Стварна функција производње информација јесте у томе да начини замешатељство у разликовању битног и небитног, постојећег и непостојећег, лажи и истине, односно у корумпирању самих критеријума њиховог разликовања. Басара се енциклопедијском формом служи још од Фаме о бициклистима на специфичан начин: он је у исти мах гради и разграђује. То значи да задржава њен облик, али је семантички трансформише у својеврсну параноидну епистемологију: архивско је истраживање и мотивисано разобличавањем конспирација. Треба објединити све да би се сазнала тек мрвица могуће истине, која би се сазнала у сваком случају. Као мали лексикон болести и здравља, каталог завера, лажи и мистификација, Басарин роман открива да је свет пуко игралиште (због чега није мање опасан), а то је духовна истина првог реда, која се појављује као нуспроизвод широко елаборираних тема о немогућности сазнања и одсуству смисла свих збивања. Ратови и катастрофе, револуције, побуне и гулази - све то има свој узрок изван оног што се уобичајено сматра узроком и Успон $u$ пад Паркинсонове болести сведочи о истинској каузалности која стоји испод онога што фигурира као истина. Параноидни дискурс обележава Паркинсонове текстове и открива се пре свега у његовој опсесији катастрофом, коју својим деловањем треба да спречи. Обзнањујући конспирацију здравих, лекара, хипохондара, те конспиративну природу великих историјских догађаја, Паркинсон огољава властити поглед на свет. Док о себи мисли и пише као о ловљеном, цензурисаном, прокаженом, читалац има све разлоге да о њему мисли као о ловцу. У основи Паркинсонових уверења је бинарна опозиција: јунак себе види као спасиоца света наспрам оних који га урушавају и фалсификују његову спасоносну болест, будући да је његову идеологију поразила идеологија здравља. Уосталом, Вознесенски и закључује да је он контрареволуционар и вођа тајног друштва које умало није променило ток руске историје. 
Паркинсонизам, та болест чији је изумитељ, а заправо је тек „последњи бодисатва” Д. Л. Паркинсон, заправо је „тамна ноћ душе” о којој је писао мистик Јован од Крста, а која у Басариној верзији подразумева свест о палости душе, властитој духовној конфузији и безначајности. Паркинсонизам је стога болест снажних спознајних капацитета, која има чистилишну природу; незадовољство собом и свест о властитој палости ослобађа оболелог појединца гордељиве самосвести, и стога је света болест супростављена задовољству и самозадовољству здравих, а заправо успаваности остатка света. Разликовање болесних и здравих подражава новозаветно разликовање живих и мртвих, само што је лишено његовог дословног садржаја; без духовног устројства живот је немогућ и стога је само постојање болест. Зато и Басарино поигравање мртвима и живима (Паркинсон након смрти ступа у турску војску, а преписку са Соловјовим наставља и након његове смрти) почива на развијању идеје да између искључиво биолошког живота и смрти нема никакве разлике. У свету и нема здравих, само болесних који нису свесни да су болесни (здрави = успавани), те се Паркинсонизам појављује као ширење свести о властитој болести; сама свесност је већ каква-таква клица духа, односно здравља. У савременом свету нико није носилац истинске духовности - свест о њеном одсуству симптом је Паркинсонизма и сигнал духовног буђења, те су оболели последње оазе боготражитељства. Паркинсоновци, међутим, са параноичарима деле уверење да ништа није како треба да буде са човеком и светом.

Ако постоји некакво средиште у овом децентрираном роману онда је то с једне стране текст „Последњи дани и смрт Јакоба Бемеа” (на идејном плану то је „Tractatus antiheliocentrikus”), стога што се елементи Бемеове судбине понављају у Д. Л. Паркинсону, а ови у Вознесенском, те „последњи бодисатва паркинсонизма", како то на први поглед изгледа, преноси мистички Бемеов наук. Мада су извесна Бемеова уверења - „добро се открива кроз зло” (Берђајев 2003: 14) и све се разоткрива „кроз супротстављање” (Берђајев 2003: 11), небо и пакао су у човековој души, мит о андрогином Адаму и његовом двоструком паду - уткана у причу, њу приповеда наивни, депатетизовани приповедач (в. Рогач 2013: 14), због чега је утисак који се завештава читаоцу амбивалентан: шегрт своју повремену сумњичавост спрам учитеља открива као мањкавост властитог духа, али својом нарацијом упорно релативизује Бемеову духовност. Тако казује да Беме, да се не би превише узнео, понекад лаже, а нешто касније да и „Отац лажи” понекад каже истину; из угла таквог приповедача пародијски одјекују и други Бемеови савети, нпр. о угледању на Христа: „Зато су, драги моји, свака срамота и свака патња драгоцени. Срамотите се, патите и веселите се!” (Басара 2007: 132).

Осим имена, времена и места у коме је живео, те заната којим се бавио, Басарин, односно Паркинсонов Беме једва да има нешто заједничко са сликом коју о овом мистику садржи званична историја и филозофија. Право је питање зашто је уопште именован као Јакоб Беме, јер он функционише као знак, на исти начин на који се у тексту романа појављују Берђајев, Фјодоров са својом идејом ,заједничког дела”, те Соловјов, који је „шпијун Ватика- 
на". Њихова имена Басара користи као сигнале религиозне димензије дела, а не као репрезентанте истинске духовности. Фалсификовано је све - не само историја, него и духовност, па је стога и читаочев хоризонт очекивања изневерен, јер нема никакве разлике између две групе људи које се напоредо појављују у роману: с једне стране, Лењин, Стаљин, Мустафа Кемал, с друге Фјодоров, Берђајев, Соловјов, и лутеранац, мистик Беме.

Будући да је реч о Паркинсоновом апокрифном тексту, узрочност која је деловало као да тече од Бемеа ка Паркинсону, разоткрива свој обрнути смер: Паркинсон се појављује као фалсификатор који у Бемеов живот уписује садржаје властитог. Стога је он и прави адресант гомиле бласфемичних исказа: посредством депатетизованог приповедача, шегрта, којег пародира, Паркинсон указује на чак и нехотично искривљавање мистичких учења, али у исти мах ни сам није невин у пародирању централног јунака свог апокрифног списа. Користећи фигуру овог теозофа, визионара и творца митова Паркинсон ствара сопствени мит: тако у само средиште мистичког Бемеовог наука смешта параноидну истину: „Ништа није онако како изгледа” (Басара 2007: 116). Тотализујућа слика света остварена је у параноидном уму, као параноидни тотализујући универзум.

Паркинсон се маскира различитим идентитетима, како би се заштитио од прогона тајних служби, али је замена идентитета и део његове идеологије - ова се ослања на православна учења о греху гордости, која изобличава узимајући их у дословном значењу, те су на ивици јереси или сасвим бласфемичне. Да не би искусио удобност у самом себи, „што је равно духовној смрти" (Басара 2007: 68), Паркинсон страх од самозадовољства превазилази гомилом лажних идентитета, тврдећи и да је истински мистик онај за кога нико не зна да постоји, и цитира старца Зосиму који је за његовог оца, који је већ дотако пакао потпуне грешности, закључио да је потребно само да се покаје: „Он је спасен јер му је свеједно ко је, а најчешће то уопште и не зна” (Басара 2007: 69). Превазилажење греха гордости изобличава се у свесно манипулисање маскама.

Интерпретације у Паркинсоновим ауторским текстовима („,Tractatus antiheliocentrikus”, „Последњи дани и смрт Јакоба Бемеа”, „Историја моје болести") почивају на сржним уверењима да је свет уроњен у хаос, те да ствари нису на својим местима, а да је разликовање добра и зла замењено категоријом пријатно/непријатно. Из његовог видокруга све је јасно и све је повезано: идеја хелиоцентризма, урбанистичке промене (недостатак градских зидина), општа регресија у доба ренесансе и раслабљеност и истрошеност човечанства због претераног предавања уживањима. Тако свеопштој неповезаности света јунак супротставља чврст, логички систем којим објашњава све феномене, показујући и типичну параноидну црту закључивања без довољног броја података: тврдња да је неред све већи што је више манастира у земљи, а што илуструје бројем манастира у Русији у односу на њихов број у западноевропским протестантским земљама, део је апсурдног резоновања. Такво је, на пример, и разликовање правих и лажних мистика, из којег следи да није понашање или каквоћа личности оно што разликује мистика од не- 
мистика: „Али то је усуд мистичног пута: да се воли оно што би природно требало да се мрзи; да човек никад није сасвим начисто да ли је његова понизност и смиреност последица одважног корачања узаном стазом спасења или најобичнија слабост карактера" (Басара 2007: 111). У логичко и јасно резоновање у коме је све са свим повезано тако да се уобличава у систем, продиру повремено и произвољности које сигнализирају да су Паркинсонова уверења делузије или пак прецењене идеје „које могу бити опасније од делузија" (Кантор 2004: 37) - оба термина из регистра параноидног стила који подразумева „способност откривања односа између очигледно неповезаних ствари" (Кантор 2004: 15). Паркинсон, попут сваког параноичара, прича организовану причу, усмерену на то да порази своје непријатеље: стога се његов трактат може разумети као пример интелектуалне мономаније, како је параноју дефинисао још Крафт Ебинг.

Прича о прогнаној духовности препуштена је Паркинсону, а овај је реализује као наративни пројекат, рационалистички чврст и непропустљив за случајности: у својим текстовима он интерпретира појаве од ренесансе до модерног доба стварајући Генеалошко стабло великих болесника од Јова и других старозаветних примера до самога себе. Исто тако, он открива алтернативне мотивације важних историјских догађаја, а коначан циљ историјских процеса види као растеловљење људских бића. „Параноидни наратив не настаје ex nihilo, пре га треба видети као читање текста универзума. Текст мора бити читан и ишчитаван све док перфектно не буде одговарао параноидној свести" (Дејвис 2005: 13). За читаочев закључак да је Паркинсон грандиозни тип параноика а његове идеје тек параноидна артикулација алтернативног система веровања непремостиву препреку представљају патолошке промене у животу Вознесенског, које се догађају под утицајем читања о Паркинсонизму и потврђују истинитост Паркинсонових тврдњи. Аутор, који се дискретно легитимише као Паркинсонов следбеник, у исти мах завештава идеју да сваки покушај рационализовања историјске стихије (о чему сведоче Паркинсонови текстови), свако глобално објашњење које у себи садржи чврст каузалитет, може бити осумњичено и одбачено као параноично.

Успон и пад Паркинсонове болести показује „однос постмодернистичке многострукости и параноидне ригидности" (О’Донел 2000: VII) као однос узрока и последице, и то тако што их ставља напоредо, не завештавајући читаоцу никакав коначан суд. Паркинсонова параноидна слика света појављује се као алтернатива хаосу (Фарел 2006: 5), чиме се Басара потврђује као аутор на пинчоновском трагу. Пошто је реалност доведена у питање, а постмодерна многострукост се с разлогом може сматрати - и Басара је томе идејно близак - празном раздробљеношћу, оно чиме се оперише као информацијом и знањем у ствари је само низ параноидних претпоставки.

Успон и пад Паркинсонове болести дијагностикује стање у коме је повећање непоузданости света паралелно с растом објашњавалачких дискурса које је лако дисквалификовати као параноидне, али се тиме ипак нешто значајно губи и субјекат тоне у хаос. Оно што је опасно (параноја), сагледано са вишег нивоа, постаје спасоносни оквир - „Знајте да је оно што нам изгледа 
зло у ствари добро (...) Памтите шта је рекао Мартин Лутер: 'Тамо где је боље, тамо је двапут горе"” (Басара 2007: 103) - јер је најнепожељније духовно стање (а често и сами извор зла), следи из Басариног романа, узимати озбиљно свет који није друго до игралиште у коме наступају маске.

\section{ЛИТЕРАТУРА}

Бacapa 22007: S. Basara, Uspon i pad Parkinsonove bolesti, Beograd: Dereta. Берђајев 2003: N. Berđajev, Jakob Beme, Beograd: B. Kukić, Čačak: Gradac.

Владушић 2007: С. Владушић, На промаји: студије, есеји и критике, Зрењанин: Агора.

Дејвис 2005: M. Davis, Reading the Text That Isn't There: Paranoia in the Nineteenth-Century, New York, London: Routledge.

Кантор 2004: M. Kantor, Understanding paranoia: a guide for professionals, families, and sufferers, London: Praeger.

Макхејл 1992: Brian Mc Hale, Constructing Postmodernism, London, New York: Routledge.

O’Донел 2000: Patrick O’Donnell, Latent Destinies: Cultural Paranoia and Contemporary U. S. Narrative, Durham and London: Duke University Press.

Рогач 2013: Маја Рогач. „Портрет једне пародије”. Кюижевни портрет Светислава Басаре. Зборник 29. књижевних сусрета Савремена српска проза, 9-10. новембар 2012, број 25, Трстеник: Народна библиотека „Јефимија", 11-20.

Татаренко 2008: Ала Татаренко, „Роман као држава, држава као роман: прилог проучавању књижевне политике српског постмодернизма". Српски језик, књижевност, уметност: зборник радова са научног скупа одржаног на Филолошко-уметничком факултету у Крагујевцу 26. и 27. октобра 2007. Књ. 2. Кюижевност, друштво, политика, Крагујевац: Филолошко-уметнички факултет: Скупштина града.

Фарел 2006: J. Farell, Paranoia and Modernity: Cervantes to Rousseau, New York: Cornell University Press.

Jasmina M. Ahmetagić

\section{ENCYCLOPEDIC FORM AND PARANOID EPISTEMOLOGY IN THE NOVELS OF SVETISLAV BASARA}

\section{(Summary)}

In the examination of the encyclopedic paradigm of the postmodern Serbian novel, the oeuvre of Svetislav Basara holds a prominent position, being that, ever since The Cyclist Conspiracy, he has been simultaneously constructing and deconstructing the form of encyclopedia: he has kept its basic 
form, while also transforming it semantically into a distinct epistemology of paranoia. On the other hand, Basara's oeuvre contains an entire encyclopedia of Eastern Orthodox thought, which acts as a counterpoint to the deviations of ideology and the identity-related conversions of an ontologically weakened subject. From a thus defined position, we have contemplated the encyclopedic form in The Rise and Fall of Parkinson's Disease, achieved in the form of a collection of papers (interpretations) about one particular topic. Basara's novel is a brief lexicon of illness and health, but also a catalogue of madness, illness, conspiracies, lies, and mystifications. Everything has been forged - not just history, but spirituality as well, and for that reason the reader's horizon of expectations has also been betrayed, because in The Rise and Fall there is no difference at all between the two groups of people that appear alongside each other in the novel: with Lenin, Stalin, Mustafa Kemal on one side, but also Fyodorov, Berdyaev, Solovyov, and a Lutheran, the mystic Böhme on the other. Being aware of spirituality's absence is a symptom of Parkinsonism and a signal of spiritual awakening, which makes the ill the last oases of seeking god and meaning. The Parkinsonians, however, share the belief of the paranoiacs that nothing is the way it should be with man and the world. We have explored the semantics and the functionality behind Basara's encyclopedic form, as well as its treatment of the discourse of paranoia. The encyclopedic form - which Basara realizes through the breadth of his scope and the text's decentered form - validates the paranoid epistemology in an ontologically unsteady world. 